\title{
Plant Responses to Nanoparticle Stress
}

\author{
Zahed Hossain ${ }^{1, *}$, Ghazala Mustafa ${ }^{2}$ and Setsuko Komatsu ${ }^{2, *}$ \\ Received: 14 September 2015 ; Accepted: 23 October 2015 ; Published: 6 November 2015 \\ Academic Editor: Jianhua Zhu \\ 1 Department of Botany, University of Kalyani, Kalyani 741235, West Bengal, India \\ 2 National Institute of Crop Science, National Agriculture and Food Research Organization, Tsukuba \\ 305-8518, Japan; ghazalamustafa@affrc.go.jp \\ * Correspondence: zahed_kly@yahoo.com (Z.H.); skomatsu@affrc.go.jp (S.K.); \\ Tel.: +91-33-2582-8750 (ext. 217) (Z.H.); +81-29-838-8693 (S.K.); \\ Fax: +91-33-2582-8282 (Z.H.); +81-29-838-8694 (S.K.)
}

\begin{abstract}
With the rapid advancement in nanotechnology, release of nanoscale materials into the environment is inevitable. Such contamination may negatively influence the functioning of the ecosystems. Many manufactured nanoparticles (NPs) contain heavy metals, which can cause soil and water contamination. Proteomic techniques have contributed substantially in understanding the molecular mechanisms of plant responses against various stresses by providing a link between gene expression and cell metabolism. As the coding regions of genome are responsible for plant adaptation to adverse conditions, protein signatures provide insights into the phytotoxicity of NPs at proteome level. This review summarizes the recent contributions of plant proteomic research to elaborate the complex molecular pathways of plant response to NPs stress.
\end{abstract}

Keywords: nanoparticles; oxidative stress; proteomics

\section{Introduction}

Nanotechnology is an emerging multidisciplinary field with a wide range of applications in cancer therapy, targeted drug delivery, electronics, cosmetic industry, and biosensors [1]. Nevertheless, unspecified release of metal-based nanoparticles (NPs) into the ecosystem has raised global concern about their potential phytotoxic effects. The NPs are extremely fine particles with lengths between 1 and $100 \mathrm{~nm}$ in at least two of their dimensions [2]. These are in fact intermediate in size between molecules and bulk materials. Division of bulk materials into smaller and smaller pieces gives them very unique physical and chemical properties [3]. Moreover, a high surface-to-volume ratio renders these nanoscale materials highly reactive or catalytic.

Bulk production of NPs often leads to their indiscriminate release in nature through industrial waste-waters $[4,5]$. A majority of the manufactured NPs contain heavy metals. Thus, soil and water contamination with metallic NPs has become an important environmental issue. Nanoparticles interact with the plants and results in the uptake and accumulation that affect their fate and transport in the ecosystem. Moreover, NPs could remain attached to the plant surface and impart physical and chemical damage to the plant organs. Usually, NPs enter the plant root system through the lateral root junctions and reach the xylem through the cortex and the pericycle [6]. Notably, NPs' entry into the plant can be stopped by the cell wall. The specific properties of cell wall allowing the transport of NPs could be attributed to the pore size of cell wall [7]. The NPs that are in the size range within the cell wall pore size could effectively cross the cell wall and reach the plasma membrane [8]. The rate of entry depends on the size and surface properties of NPs. Indeed, the smaller NPs can enter into plant cells easily. In contrast, larger NPs, being unable to enter the cells, cannot affect the cell metabolic pathways [9]. Larger NPs can only penetrate through the hydathodes, flower stigmas, 
and stomata. Mechanism of interaction between NPs and plants could be chemical or physical. Chemical interactions involve the production of reactive oxygen species [1], disturbance of ion cell membrane transport activity [10], oxidative damage [11], and lipid peroxidation [12]. Following entry into the plant cells, NPs after mixing behave as metal ions and react with sulfhydryl, carboxyl groups and ultimately alter the protein activity. However, while conducting engineered nanomaterials (ENMs) mediated ecotoxicity study, much attention needs to be paid towards various artifacts which often lead to misinterpretations of results [13]. These potential factors include toxic impurities in ENM materials, their proper storage and dispersion in testing medium. Moreover, ENMs exert indirect toxicity which affects plant growth and development through nutrient depletion with passage of time, and estimation of ENM dispersal in organisms. In addition, ENMs face different changes (viz. settling, dissolution, agglomeration, etc.) during the exposure period, which is difficult to measure accurately. Due to increased surface area and properties, ENMs readily adsorb organic molecules and inorganic ions from the nutrient medium resulting indirect toxicity symptoms including chlorosis and wilting [14,15]. Moreover, during ENM exposure, organic acid in plant root exudates decreases the $\mathrm{pH}$ of the media, thus altering nutrient supply and ENM properties [16]. Inefficiency to explore the influence of these factors can direct to an inappropriate explanation of phytotoxicity and ultimately a fabricated impact of ENMs [13].

\section{Plant Response to Nanoparticle Stress}

NPs with different composition, size, and concentration, physical/chemical properties have been reported to influence growth and development of various plant species with both positive and negative effects [17]. Khodakovskaya et al. [18] reported that multi-walled carbon nanotubes markedly influenced tomato seed germination and seedling growth by up-regulating stress-related gene expression. In Arabidopsis, $\mathrm{Al}_{2} \mathrm{O}_{3}$-NPs were reported to be least toxic compared to zinc oxide, iron oxide, and silicon oxide nanoparticles [19]. Previous study highlighted the toxic effects of NPs on algae [20]. NPs like titanium oxide, zinc oxide, cerium oxide, and silver NPs were deposited on the surface of cell as well as in the organelles, which resulted in oxidative stress to the cell through the induction of oxidative stress signaling [21]. In Cucurbita pepo, the effect of silver, copper $(\mathrm{Cu})$, zinc oxide, and silicon nanoparticles indicated that seed germination was unaffected by these NPs and their counterpart bulk materials; however, $\mathrm{Cu}$ nanoparticles reduced root length compared to the control and plants treated with the bulk $\mathrm{Cu}$ powder [22]. In rice, $\mathrm{ZnO}$ NPs, but not titanium oxide cause deleterious effects on the root length at early growth stages [23]. Riahi-Madvar et al. [24] indicated that the root growth of Triticum aestivum was affected by different concentrations of the alumina-nanoparticles; however, NPs did not affect the seed germination, shoot length, and dry biomass. In rice seedlings, nano- $\mathrm{CuO}$ treatment led to an increase in activity of antioxidant enzymes and elevated MDA concentration [25]. A similar experiment on the nano- $\mathrm{CuO}$ modulated photosynthetic performance and antioxidative defense system in Hordeum vulgare demonstrated restriction in root and shoot growth with decreased photosynthetic performance index [26]. Moreover, nano-CuO mediated DNA damage and plant growth restriction were reported in radish (Raphanus sativus) and ryegrass (Lolium perenne and Lolium rigidum) [27]. Changes in enzyme activities, ascorbate and free thiol levels resulting in higher membrane damage and photosynthetic stress have been documented in shoots of germinating rice seedlings on exposure to very high concentration of cerium oxide NPs [28]. Generation of ROS and reactive nitrogen species and $\mathrm{H}_{2} \mathrm{O}_{2}$ upon exposure to $\mathrm{Ag}$ and $\mathrm{ZnO}$ engineered NPs on the duckweed (Spirodela punctuta) suggest that toxicity of $\mathrm{Ag}$ and $\mathrm{ZnO}-\mathrm{NPs}$ predominantly caused by both the particulates and ionic forms [29].

Among the various metal NPs, much attention has been paid to Ag-NP owing to their characteristic physiochemical and biological properties compared to the massive bulk material [30]. The Ag-NPs have wide applications as an essential component in different products like household, food, and industries because of their bactericidal and fungicidal properties [31]. Compared to the 
silver-based compounds, Ag-NPs, with increased surface area available for microbe interaction, are reported to be more toxic to bacteria, fungi, and viruses. Like other metal ions, Ag-NPs can also induce oxidative stress in bacteria, animals, algae as well as higher plants [32]. However, the impact of Ag-NPs on plants largely depends on various factors such as plant species, growth stage of plant, composition and concentration of the nanoparticles, and the experimental setup (temperature, treatment period, media composition, and method of exposure, etc.) [33]. Nano-Ag is one of the most extensively studied NPs whose toxicology has been examined in various crops [22,32,34]. Although Ag-NPs exposure is reported to be detrimental for plant growth, some studies have demonstrated the growth-enhancing properties of Ag-NPs in Brassica juncea [35], Eruca sativa [33], wetland plants [36], and Phaseolus vulgaris and Zea mays [37]. An investigation by Kumari et al. [34] revealed chromotoxic effects of Ag-NPs on the mitotic cell division in root-tip cells of Allium cepa. Moreover, Ag-NPs interact with the membrane proteins and activate signaling pathways, that leads to inhibition of cell proliferation [38,39].

Perusal of all these nanotoxicity studies over the past decade reveals that plant response to NPs stress has been evaluated extensively in various crops largely at physiological and biochemical levels. Rather less focus has been given to the study of plant-NPs interface at transcript level (Table 1). Microarray-based gene expression analysis of Arabidopsis thaliana roots on exposure to $\mathrm{ZnO}-\mathrm{NPs}, \mathrm{TiO}_{2}-\mathrm{NPs}$, and fullerene soot indicates that the underlying mechanisms of phytotoxicity are highly specific to the nanoparticle [40]. Khodakovskaya et al. [41] designed an advanced method by amalgamating genetic, photothermal, and photoacoustic strategies for highly sensitive detection of NPs in different parts of tomato plants, most importantly the reproductive organs. Total gene expression analysis of tomato leaves and roots exposed to carbon nanotubes (CNTs) revealed up-regulation in the stress and water channel-related genes. A separate study demonstrated selective root growth in maize upon exposure to single-walled carbon nanotubes (SWCNTs) [42]. Transcriptional analysis suggests that nanoparticle-root cell interaction selectively modulates gene expression in seminal roots, thus affecting relative root growth and development. Similar to transcriptome analysis, only limited numbers of studies have emphasized the effects of nanoparticles stress on plants at proteome level.

\section{Modulation of Proteome Composition under Nanoparticle Stress}

Over the past decade, phytotoxicity of Ag-NPs has been evaluated extensively in various crops, largely at morphological, physiological, and biochemical levels. However, only limited studies have emphasized the effects of Ag-NPs stress on plants at proteome level (Table 2). Recently, Mirzajani et al. [43] performed a gel-based proteomic study to understand the effects of Ag-NPs toxicity on Oryza sativa. The root proteome study revealed that Ag-NPs-responsive proteins were primarily associated with oxidative stress response pathway, $\mathrm{Ca}^{2+}$ regulation and signaling, transcription, protein degradation, cell wall synthesis, cell division, and apoptosis. Increased abundance of defense-related proteins including superoxide dismutase, L-ascorbate peroxidase, glutathione-S-transferase implies accelerated production of ROS under Ag-NPs treatment. It has been hypothesized that Ag-NPs or released ions impede cell metabolism by binding to second messenger calcium ion receptors, calcium ion channels, and $\mathrm{Ca}^{2+} / \mathrm{Na}^{+}-\mathrm{ATPases}$.

Proteomic study on Eruca sativa roots exposed to Ag-NPs and $\mathrm{AgNO}_{3}$ revealed that both forms of Ag caused changes in the proteins related to redox regulation, disrupting cellular homeostasis (Figure 1) [33]. However, the Ag-NPs alone were responsible to alter the ER and vacuolar proteins, thus indicating these organelles as target sites of Ag-NPs. These findings suggest that phytotoxicity of Ag-NPs is primarily due to their characteristic physiochemical properties, and not by releasing the $\mathrm{Ag}^{+}$[33]. We also studied the toxicity mechanisms of Ag-NPs on early-stage-soybean growth under flooding stress [44]. In total, three different particle sizes $(2,15$, and 50-80 nm) and concentrations $(0.2$, 2, and $20 \mathrm{ppm}$ ) were screened. The Ag-NPs of $15 \mathrm{~nm}$ facilitated the soybean growth under flooding, compared to the larger and smaller nanoparticles. The changed proteins under Ag-NPs exposure were mainly related to stress, signaling, and cell metabolism. 
Table 1. Summary of gene expression analyses in response to nanoparticle stress.

\begin{tabular}{|c|c|c|c|c|c|c|c|}
\hline Plant (Cultivar) & Tissue/Organ & $\begin{array}{l}\text { Growth } \\
\text { Stage }\end{array}$ & $\begin{array}{c}\text { Nanoparticles } \\
\text { (Particle Size, Dose) }\end{array}$ & $\begin{array}{l}\text { Treatment } \\
\text { Period }\end{array}$ & Technique & Major Findings & Ref \\
\hline $\begin{array}{l}\text { Arabidopsis thaliana } \\
\text { accession } \\
\text { Columbia-0 }\end{array}$ & Root & 3-week-old & $\begin{array}{l}\mathrm{Ag}(10-80 \mathrm{~nm}), \mathrm{TiO}_{2} \\
(10-40 \mathrm{~nm}), \mathrm{MWNT}\end{array}$ & 7 days & $\begin{array}{l}\text { Microarray } \\
\text { analysis }\end{array}$ & $\begin{array}{c}\text { Exposure to NPs repressed expression } \\
\text { of phosphate-starvation and } \\
\text { root-development genes. }\end{array}$ & [45] \\
\hline $\begin{array}{l}\text { Arabidopsis thaliana } \\
\text { (ecotype, Columbia) } \\
\text { Wild, tir1, abi5 } \\
\text { mutants }\end{array}$ & Seedling & 4-day-old & $\begin{array}{l}\text { Ag-NPs: triangular } \\
(47 \mathrm{~nm}) \text {, spherical } \\
(8 \mathrm{~nm}), \text { decahedral } \\
(45 \mathrm{~nm})\end{array}$ & 3 days & qRT-PCR & $\begin{array}{l}\text { Ag-NPs induced ROS accumulation; } \\
\text { interfered with ethylene biosynthesis; } \\
\text { promoted root growth; triggered gene } \\
\text { expression involved in cellular } \\
\text { events-cell proliferation, metabolism, } \\
\text { and hormone signaling pathways. }\end{array}$ & [46] \\
\hline $\begin{array}{l}\text { Arabidopsis thaliana } \\
\text { (Col-0/Redei-L211497) }\end{array}$ & Seedling & Germinating & $\begin{array}{l}\text { Ag-NPs }(20 \mathrm{~nm} ; \\
5 \mathrm{ppm})\end{array}$ & 10 days & $\begin{array}{l}\text { Microarray } \\
\text { analysis }\end{array}$ & $\begin{array}{l}\text { Up-regulated genes primarily } \\
\text { associated with metals and oxidative } \\
\text { stress, while down-regulated genes } \\
\text { linked to biotic and hormonal stimuli. }\end{array}$ & [47] \\
\hline $\begin{array}{l}\text { Chlamydomonas } \\
\text { reinhardtii } \\
\text { (wild-type strain } \\
\text { C137) }\end{array}$ & - & - & $\begin{array}{c}\mathrm{Ag}(20 \mathrm{~nm} ; 1 \mathrm{ppm}) \\
\mathrm{TiO}_{2}(5 \mathrm{~nm} ; 1 \mathrm{ppm}) \\
\mathrm{ZnO}(20 \mathrm{~nm} ; \\
1 \mathrm{ppm}), \mathrm{QDs} \\
(6-10 \mathrm{~nm}, 0.12 \mathrm{ppm})\end{array}$ & $2 \mathrm{~h}$ & $\begin{array}{l}\text { RNA-seq } \\
\text { analysis }\end{array}$ & $\begin{array}{l}\text { Genes associated with photosynthesis } \\
\text { were markedly decreased on exposure } \\
\text { to } \mathrm{TiO}_{2} \text {. Ag-NPs exposure led to the } \\
\text { elevation of transcripts encoding } \\
\text { components of cell wall and flagella. }\end{array}$ & {$[48]$} \\
\hline $\begin{array}{l}\text { Arabidopsis thaliana } \\
\text { (wild type, cv. } \\
\text { Columbia) }\end{array}$ & Root & 3-week-old & $\begin{array}{c}\mathrm{ZnO}(<100 \mathrm{~nm} ; \\
100 \mathrm{ppm}), \mathrm{TiO}_{2} \\
(<150 \mathrm{nM} ; 100 \mathrm{ppm}) \\
\mathrm{FS}(100 \mathrm{ppm})\end{array}$ & 7 days & $\begin{array}{l}\text { Microarray } \\
\text { analysis }\end{array}$ & $\begin{array}{l}\text { Both abiotic (oxidative, salt, water } \\
\text { deprivation) and biotic (wounding and } \\
\text { defense to pathogens) stress responsive } \\
\text { genes were up-regulated under ZnO } \\
\text { and FS; while cell organization and } \\
\text { biogenesis associated genes were } \\
\text { down-regulated upon ZnO-NPs. }\end{array}$ & [40] \\
\hline
\end{tabular}

Abbreviation: FS, fullerene soot; MWNT, multi-wall nanotubes; QDs, CdTe/CdS quantum dots. 
Table 2. Summary of proteomic analyses in response to nanoparticle stress.

\begin{tabular}{|c|c|c|c|c|c|c|c|}
\hline Plant (Cultivar) & Organ & $\begin{array}{l}\text { Growth } \\
\text { Stage }\end{array}$ & $\begin{array}{c}\text { Nanoparticles } \\
\text { (Particle Size, Dose) }\end{array}$ & $\begin{array}{l}\text { Treatment } \\
\text { Period }\end{array}$ & Technique & Major Findings & Ref. \\
\hline $\begin{array}{l}\text { Soybean (Glycine } \\
\max \text { L. cv. Enrei) }\end{array}$ & $\begin{array}{l}\text { Root } \\
\text { including } \\
\text { hypocotyl }\end{array}$ & 2-day-old & $\begin{array}{c}\mathrm{Ag}, \mathrm{ZnO} \\
\mathrm{Al}_{2} \mathrm{O}_{3}-\mathrm{NPs} \text { with } \\
\text { flooding stress } \\
(0.5-500 \text { ppm })\end{array}$ & $1-3$ days & $\begin{array}{c}\text { Gel-free } \\
\text { (nanoLC MS/MS) }\end{array}$ & $\begin{array}{l}\mathrm{Al}_{2} \mathrm{O}_{3}-\mathrm{NPs}(50 \mathrm{ppm}) \text { promote seedling } \\
\text { growth under flooding stress by regulating } \\
\text { energy metabolism and cell death. }\end{array}$ & [49] \\
\hline $\begin{array}{l}\text { Soybean (Glycine } \\
\max \text { L. cv. Enrei) }\end{array}$ & $\begin{array}{l}\text { Root, } \\
\text { cotyledon }\end{array}$ & 2-day-old & $\begin{array}{l}\text { Ag-NPs with } \\
\text { flooding stress }(2, \\
15,50-80 \mathrm{~nm} ; 0.2,2 \\
20 \mathrm{ppm})\end{array}$ & $1-4$ days & $\begin{array}{c}\text { Gel-free } \\
\text { (nanoLC MS/MS) }\end{array}$ & $\begin{array}{l}\text { Ag-NPs (15 nm: } 2 \text { ppm) treatments facilitate } \\
\text { seedling growth under flooding stress. } \\
\text { Decreased abundance of glyoxalase II } 3 \text { and } \\
\text { fermentation-related proteins: pyruvate } \\
\text { decarboxylase } 2 \text { and alcohol dehydrogenase } \\
\text { 1, indicating metabolic shift from } \\
\text { fermentative pathways towards normal } \\
\text { cellular processes. }\end{array}$ & {$[44]$} \\
\hline $\begin{array}{l}\text { Rice (Oryza sativa L. } \\
\text { cv. IR651) }\end{array}$ & Root & 10-day-old & Ag-NPs $(30,60$ ppm) & 20 days & $\begin{array}{c}\text { Gel-based (2-DE, } \\
\text { nanoLC/FT-ICR MS) }\end{array}$ & $\begin{array}{l}\text { Increased abundance of proteins related to } \\
\text { oxidative stress response pathway, } \mathrm{Ca}^{2+} \\
\text { regulation signaling, transcription, protein } \\
\text { degradation, cell wall synthesis, cell } \\
\text { division and apoptosis. }\end{array}$ & {$[43]$} \\
\hline $\begin{array}{l}\text { Eruca sativa } \\
\text { (common name: } \\
\text { rocket) }\end{array}$ & Root & $\begin{array}{l}\text { Germinating } \\
\text { seeds }\end{array}$ & $\begin{array}{l}\mathrm{Ag}-\mathrm{NPs} \text { or } \mathrm{AgNO}_{3} \\
(0.1,1,10,20 \\
100 \mathrm{ppm})\end{array}$ & 5 days & $\begin{array}{c}\text { Gel-based (2-DE, } \\
\text { nanoLC-nESI-MS/MS) }\end{array}$ & $\begin{array}{c}\text { Alteration of some proteins related to the } \\
\text { ER and vacuole indicating these two } \\
\text { organelles as targets of the Ag-NPs action. } \\
\text { Effects of Ag-NPs are not simply due to the } \\
\text { release of } \mathrm{Ag}^{+} \text {. }\end{array}$ & [33] \\
\hline
\end{tabular}




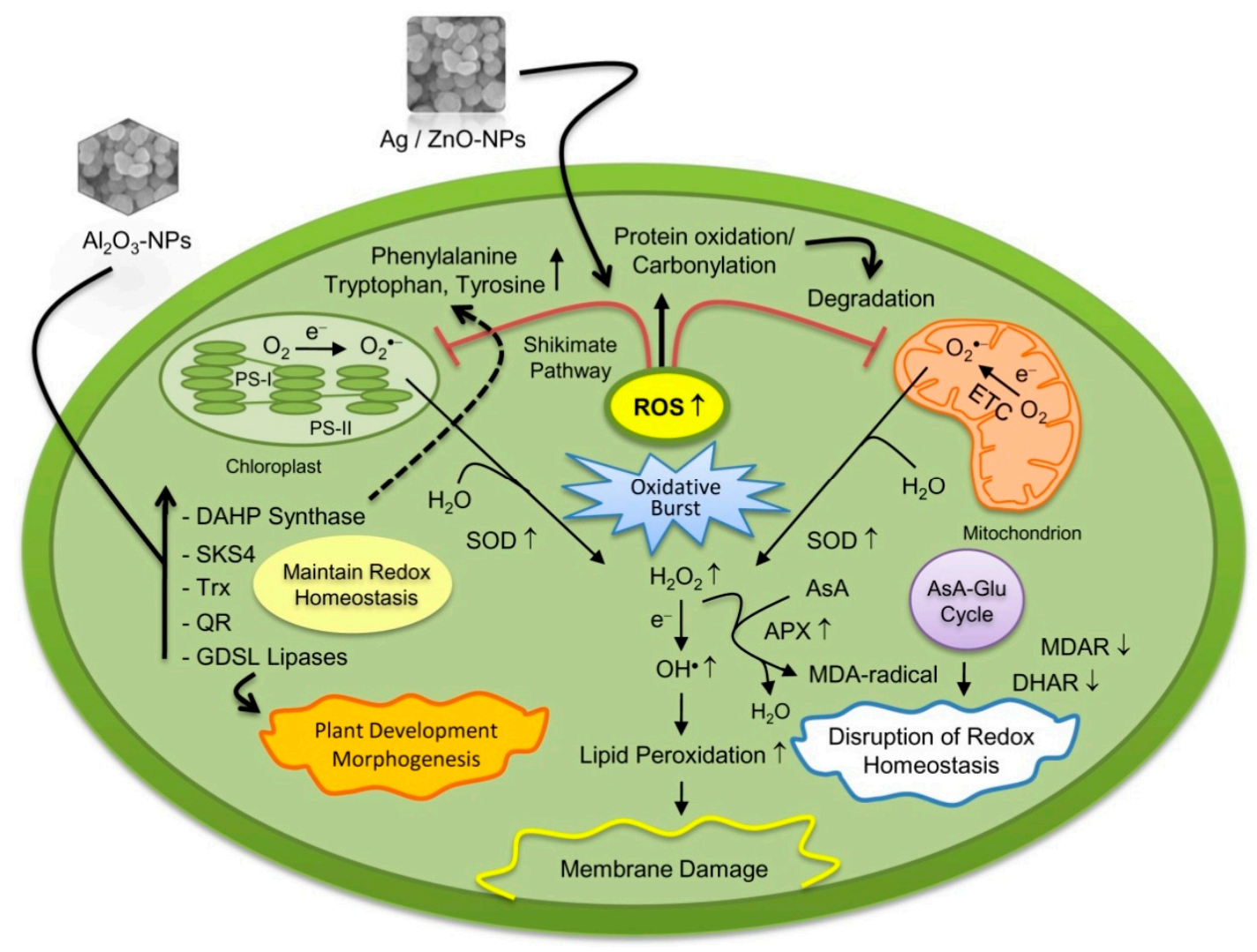

Figure 1. Cellular toxicity induced by nanoparticles (NPs). Exposure to NPs potentially leads to toxic side effects such as enhanced ROS generation, disruption of redox homeostasis, lipid peroxidation, impaired mitochondrial function, and membrane damage. Upward arrows indicate increased and downward arrows indicate decreased protein abundance in response to NPs stress, respectively. Dotted arrow represents shikimate pathway, a common biosynthetic route for the synthesis of aromatic amino acids. Abbreviations: APX, ascorbate peroxidase; AsA, reduced ascorbate; DAHP, 3-deoxy- $D$-arabino-heptulosonate-7-phosphate; DHAR, dehydroascorbate reductase; ETC, electron transport chain; $\mathrm{H}_{2} \mathrm{O}_{2}$, hydrogen peroxide; MDA, malondialdehyde; MDAR, monodehydroascorbate reductase; PS, photosystem; QR, quinone reductase; ROS, reactive oxygen species; SKS4, SKU5 similar 4 protein; SOD, superoxide dismutase; Trx, thioredoxin.

In roots and cotyledons the abundance of glyoxalase II 3, an important enzyme of glyoxalase detoxification pathway, was increased in a time-course manner under flooding stress; however, it declined in response to Ag-NPs. Furthermore, Ag-NPs treatment caused a metabolic shift from fermentative pathways towards normal cellular processes. The results suggested that the Ag-NPs (15 $\mathrm{nm}$ at $2 \mathrm{ppm}$ ) treated soybeans experienced less deprivation of oxygen, which acts as an important factor for enhanced growth of soybeans under Ag-NPs treatment with flooding stress. In contrast, high concentration of Ag-NPs (20 ppm, $15 \mathrm{~nm}$ particle size) was lethal to soybean seedlings [44].Very recently, we compared the effects of $\mathrm{Ag}$-, $\mathrm{ZnO}$ - and $\mathrm{Al}_{2} \mathrm{O}_{3}$-NPs on two-day-old soybean under flooding stress [49]. Interestingly, enhanced soybean growth was observed in $50 \mathrm{ppm}$ $\mathrm{Al}_{2} \mathrm{O}_{3}$-NPs treatment. The $\mathrm{Al}_{2} \mathrm{O}_{3}$-NPs-responsive proteins were predominantly related to protein synthesis/degradation, glycolysis, and lipid metabolism. Moreover, 5-fold enhanced abundance of NmrA-like negative transcriptional regulator family protein was recorded under $\mathrm{Al}_{2} \mathrm{O}_{3}-\mathrm{NPs}$ treatment. In summary, proteomic findings suggest that regulation of energy metabolism and reduced root cell death might promote soybean growth under flooding stress. 


\section{Conclusions and Future Prospects}

By summarizing proteomic contributions, efforts have been made in the present review to delineate the molecular basis of acquisition of nanoparticles stress response mechanism. However, only limited numbers of proteomic studies have so far been conducted in the plant system. Most of the studies carried out so far primarily deal with the overall plant response towards a specific NPs stress showing differential abundance of proteins involved in oxidation-reduction, ROS detoxification, stress signaling, and hormonal pathways. Proteomic studies on Ag-NPs induced phytotoxicity revealed that the size of the nanoparticle is the key factor in determining the type and magnitude of the cellular response. Future initiatives need to be taken to find out whether the metallic nanoparticles exert their toxicity solely due to their unique properties or to the released metal ions. Moreover, research aimed at identifying and characterizing subcellular organelle proteins are expected for exploring the precise alterations in the protein signature of cell to withstand the NPs stress. In addition to proteomics, other "omics" based high-throughput techniques such as transcriptomics and metabolomics have immense potential to evaluate the effects and toxicity of nanoscale materials $[45,50]$. Metabolomics allows fast screening for biomarkers of oxidative stress following the application of NPs. Moreover, combination of NMR- and LC/MS-based metabolomics approach is being exploited to investigate the specific pathways of interest including those related to oxidative stress, an inevitable consequence of nanoparticle exposure [50]. MALDI MS imaging technique, a powerful tool for nanotoxicology study, provides a snapshot of how NPs are distributed in tissues, which is important for characterizing and understanding nanomaterial-based toxicity [51]. Furthermore, the plant's response to combined NPs would be another topic for future "omics" based research that could highlight the possible interaction between stress signaling pathways. All these valuable information would further provide us an extensive and elaborated picture about the response mechanism of NPs stress in plants.

Acknowledgments: The authors gratefully acknowledge financial support from the National Institute of Crop Science, Tsukuba, Japan.

Author Contributions: Zahed Hossain wrote and edited, Ghazala Mustafa wrote, Setsuko Komatsu advised the review process and edited the manuscript. All authors read and approved the final version of this review article.

Conflicts of Interest: The authors declare no conflict of interest.

\section{References}

1. Nel, A.; Xia, T.; Mädler, L.; Li, N. Toxic potential of materials at the nanolevel. Science 2006, 311, $622-627$. [CrossRef] [PubMed]

2. Nowack, B.; Bucheli, T.D. Occurrence, behavior and effects of nanoparticles in the environment. Environ. Pollut. 2007, 150, 5-22. [CrossRef] [PubMed]

3. Jefferson, D.A. The surface activity of ultrafine particles. Philos. Trans. R. Soc. Lond. Ser. A 2000, 358, 2683-2692. [CrossRef]

4. $\quad$ Brunner, T.J.; Wick, P.; Manser, P.; Spohn, P.; Grass, R.N.; Limbach, L.K.; Bruinink, A.; Stark, W.J. In vitro cytotoxicity of oxide nanoparticles: Comparison to asbestos, silica, and the effect of particle solubility. Environ. Sci. Technol. 2006, 40, 4374-4381. [CrossRef] [PubMed]

5. Owen, R.; Handy, R. Formulating the problems for environmental risk assessment of nanomaterials. Environ. Sci. Technol. 2007, 41, 5582-5588. [PubMed]

6. Dietz, K.J.; Herth, S. Plant nanotoxicology. Trends Plant Sci. 2011, 16, 582-589. [CrossRef] [PubMed]

7. Fleischer, A.; O'Neill, M.A.; Ehwald, R. The pore size of non-graminaceous plant cell walls is rapidly decreased by borate ester cross-linking of the pectic polysaccharide rhamnogalacturonan II. Plant Physiol. 1999, 121, 829-838. [CrossRef] [PubMed]

8. Navarro, E.; Baun, A.; Behra, R.; Hartmann, N.B.; Filser, J.; Miao, A.J.; Quigg, A.; Santschi, P.H.; Sigg, L. Environmental behavior and ecotoxicity of engineered nanoparticles to algae, plants, and fungi. Ecotoxicology 2008, 17, 372-386. [CrossRef] [PubMed] 
9. Verano-Braga, T.; Miethling-Graff, R.; Wojdyla, K.; Rogowska-Wrzesinska, A.; Brewer, J.R.; Erdmann, H.; Kjeldsen, F. Insights into the cellular response triggered by silver nanoparticles using quantitative proteomics. ACS Nano 2014, 8, 2161-2175. [CrossRef] [PubMed]

10. Auffan, M.; Achouak, W.; Rose, J.; Roncato, M.A.; Chanéac, C.; Waite, D.T.; Masion, A.; Woicik, J.C.; Wiesner, M.R.; Bottero, J.Y. Relation between the redox state of iron-based nanoparticles and their cytotoxicity toward Escherichia coli. Environ. Sci. Technol. 2008, 42, 6730-6735. [CrossRef] [PubMed]

11. Foley, S.; Crowley, C.; Smaihi, M.; Bonfils, C.; Erlanger, B.F.; Seta, P.; Larroque, C. Cellular localisation of a water-soluble fullerene derivative. Biochem. Biophys. Res. Commun. 2002, 294, 116-119. [CrossRef]

12. Kamat, J.P.; Devasagayam, T.P.; Priyadarsini, K.I.; Mohan, H. Reactive oxygen species mediated membrane damage induced by fullerene derivatives and its possible biological implications. Toxicology 2000, 155, 55-61. [CrossRef]

13. Petersen, E.J.; Henry, T.B.; Zhao, J.; MacCuspie, R.I.; Kirschling, T.L.; Dobrovolskaia, M.A.; Hackley, V.; Xing, B.; White, J.C. Identification and avoidance of potential artifacts and misinterpretations in nanomaterial ecotoxicity measurements. Environ. Sci. Technol. 2014, 48, 4226-4246. [CrossRef] [PubMed]

14. Slomberg, D.L.; Schoenfisch, M.H. Silica nanoparticle phytotoxicity to Arabidopsis thaliana. Environ. Sci. Technol. 2012, 46, 10247-10254. [PubMed]

15. Begum, P.; Fugetsu, B. Phytotoxicity of multi-walled carbon nanotubes on red spinach (Amaranthus tricolor L) and the role of ascorbic acid as an antioxidant. J. Hazard. Mater. 2012, 243, 212-222. [CrossRef] [PubMed]

16. Marschner, H. Mineral. Nutrition of Higher Plants, 2nd ed.; Academic Press: San Diego, CA, USA, 1995.

17. Ma, X.; Geisler-Lee, J.; Deng, Y.; Kolmakov, A. Interactions between engineered nanoparticles (ENPs) and plants: Phytotoxicity, uptake and accumulation. Sci. Total Environ. 2010, 408, 3053-3061. [CrossRef] [PubMed]

18. Khodakovskaya, M.; Dervishi, E.; Mahmood, M.; Xu, Y.; Li, Z.; Watanabe, F.; Biris, A.S. Carbon nanotubes are able to penetrate plant seed coat and dramatically affect seed germination and plant growth. ACS Nano 2009, 3, 3221-3227. [CrossRef] [PubMed]

19. Lee, C.W.; Mahendra, S.; Zodrow, K.; Li, D.; Tsai, Y.C.; Braam, J.; Alvarez, P.J. Developmental phytotoxicity of metal oxide nanoparticles to Arabidopsis thaliana. Environ. Toxicol. Chem. 2010, 29, 669-675. [CrossRef] [PubMed]

20. Arouja, V.; Dubourguier, H.C.; Kasemets, K.; Kahru, A. Toxicity of nanoparticles of CuO, $\mathrm{ZnO}$, and $\mathrm{TiO}_{2}$ to microalgae Pseudokirchneriella subcapitata. Sci. Total Environ. 2009, 407, 1461-1468. [CrossRef] [PubMed]

21. Buzea, C.; Pacheco, I.I.; Robbie, K. Nanomaterials and nanoparticles: sources and toxicity. Biointerphases 2007, 2, 17-71. [CrossRef]

22. Stampoulis, D.; Sinha, S.K.; White, J.C. Assay-dependent phytotoxicity of nanoparticles to plants. Environ. Sci. Technol. 2009, 43, 9473-9479. [CrossRef] [PubMed]

23. Boonyanitipong, P.; Kositsup, B.; Kumar, P.; Baruah, S.; Dutta, J. Toxicity of $\mathrm{ZnO}$ and $\mathrm{TiO}_{2}$ nanoparticles on germinating rice seed Oryza sativa L. Int. J. Biosci. Biochem. Bioninform. 2011, 1, 282-285. [CrossRef]

24. Riahi-Madvar, A.; Rezaee, F.; Jalili, V. Effects of alumina nanoparticles on morphological properties and antioxidant system of Triticum aestivum. Iran. J. Plant Physiol. 2012, 3, 595-603.

25. Shaw, A.K.; Hossain, Z. Impact of nano-CuO stress on rice (Oryza sativa L.) seedlings. Chemosphere 2013, 93, 906-915. [CrossRef] [PubMed]

26. Shaw, A.K.; Ghosh, S.; Kalaji, H.M.; Bosa, K.; Brestic, M.; Zivcak, M.; Hossain, Z. Nano-CuO stress induced modulation of antioxidative defense and photosynthetic performance of syrian barley (Hordeum vulgare L.). Environ. Exp. Bot. 2014, 102, 37-47. [CrossRef]

27. Atha, D.H.; Wang, H.; Petersen, E.J.; Cleveland, D.; Holbrook, R.D.; Jaruga, P.; Dizdaroglu, M.; Xing, B.; Nelson, B.C. Copper oxide nanoparticle mediated DNA damage in terrestrial plant models. Environ. Sci. Technol. 2012, 46, 1819-1827. [CrossRef] [PubMed]

28. Rico, C.M.; Hong, J.; Morales, M.I.; Zhao, L.; Barrios, A.C.; Zhang, J.Y.; Peralta-Videa, J.R.; Gardea-Torresdey, J.L. Effect of cerium oxide nanoparticles on rice: A study involving the antioxidant defense system and in vivo fluorescence imaging. Environ. Sci. Technol. 2013, 47, 5635-5642. [CrossRef] [PubMed]

29. Thwala, M.; Musee, N.; Sikhwivhilu, L.; Wepener, V. The oxidative toxicity of Ag and ZnO nanoparticles towards the aquatic plant Spirodela punctuta and the role of testing media parameters. Environ. Sci. Process. Impacts 2013, 15, 1830-1843. [CrossRef] [PubMed] 
30. Sharma, V.K.; Yngard, R.A.; Lin, Y. Silver nanoparticles: Green synthesis and their antimicrobial activities. Adv. Colloid. Interface Sci. 2009, 145, 83-96. [CrossRef] [PubMed]

31. Tran, Q.H.; Nguyen, V.Q.; Le, A.T. Silver nanoparticles: synthesis, properties, toxicology, applications and perspectives. Adv. Nat. Sci. 2013, 4, 033001. [CrossRef]

32. Jiang, H.S.; Li, M.; Chang, F.Y.; Li, W.; Yin, L.Y. Physiological analysis of silver nanoparticles and $\mathrm{AgNO}_{3}$ toxicity to Spirodela polyrrhiza. Environ.Toxicol. Chem. 2012, 31, 1880-1886. [CrossRef] [PubMed]

33. Vannini, C.; Domingo, G.; Onelli, E.; Prinsi, B.; Marsoni, M.; Espen, L.; Bracale, M. Morphological and proteomic responses of Eruca sativa exposed to silver nanoparticles or silver nitrate. PLoS ONE 2013, 8, e68752. [CrossRef] [PubMed]

34. Kumari, M.; Mukherjee, A.; Chandrasekaran, N. Genotoxicity of silver nanoparticles in Allium cepa. Sci. Total Environ. 2009, 407, 5243-5246. [CrossRef] [PubMed]

35. Sharma, P.; Bhatt, D.; Zaidi, M.G.; Saradhi, P.P.; Khanna, P.K.; Arora, S. Silver naoparticle-mediated enhancement in growth and antioxidant status of Brassica juncea. Appl. Biochem. Biotechnol. 2012, 167, 2225-2233. [CrossRef] [PubMed]

36. Yin, L.; Colman, B.P.; McGill, B.M.; Wright, J.P.; Bernhardt, E.S. Effects of silver nanoparticle exposure on germination and early growth of eleven wetland plants. PLoS ONE 2012, 7, e47674. [CrossRef] [PubMed]

37. Salama, H.M.H. Effects of silver nanoparticles in some crop plants, common bean (Phaseolus vulgaris L.) and corn (Zea mays L.). Int. Res. J. Biotechnol. 2012, 3, 190-197.

38. Roh, J.Y.; Eom, H.J.; Choi, J. Involvement of Caenorhabditis elegans MAPK signaling pathways in oxidative stress response induced by silver nanoparticles exposure. Toxicol. Res. 2012, 28, 19-24. [CrossRef] [PubMed]

39. Gopinath, P.; Gogoi, S.K.; Sanpui, P.; Paul, A.; Chattopadhyay, A.; Ghosh, S.S. Signaling gene cascade in silver nanoparticle induced apoptosis. Colloids Surf. B 2010, 77, 240-245. [CrossRef] [PubMed]

40. Landa, P.; Vankova, R.; Andrlova, J.; Hodek, J.; Marsik, P.; Storchova, H.; White, J.C.; Vanek, T. Nanoparticle-specific changes in Arabidopsis thaliana gene expression after exposure to $\mathrm{ZnO}, \mathrm{TiO}_{2}$, and fullerene soot. J. Hazard. Mater. 2012, 241-242, 55-62. [CrossRef] [PubMed]

41. Khodakovskaya, M.V.; de Silva, K.; Nedosekin, D.A.; Dervishi, E.; Biris, A.S.; Shashkov, E.V.; Galanzha, E.I.; Zharov, V.P. Complex genetic, photothermal, and photoacoustic analysis of nanoparticle-plant interactions. Proc. Natl. Acad. Sci. USA 2011, 108, 1028-1033. [CrossRef] [PubMed]

42. Yan, S.; Zhao, L.; Li, H.; Zhang, Q.; Tan, J.; Huang, M.; He, S.; Li, L. Single-walled carbon nanotubes selectively influence maize root tissue development accompanied by the change in the related gene expression. J. Hazard. Mater. 2013, 246-247, 110-118. [CrossRef] [PubMed]

43. Mirzajani, F.; Askari, H.; Hamzelou, S.; Schober, Y.; Römpp, A.; Ghassempour, A.; Spengler, B. Proteomics study of silver nanoparticles toxicity on Oryza sativa L. Ecotoxicol. Environ. Saf. 2014, 108, 335-339. [CrossRef] [PubMed]

44. Mustafa, G.; Sakata, K.; Hossain, Z.; Komatsu, S. Proteomic study on the effects of silver nanoparticles on soybean under flooding stress. J. Proteom. 2015, 122, 100-118. [CrossRef] [PubMed]

45. García-Sánchez, S.; Bernales, I.; Cristobal, S. Early response to nanoparticles in the Arabidopsis transcriptome compromises plant defence and root-hair development through salicylic acid signalling. BMC Genom. 2015, 16, 341-356. [CrossRef] [PubMed]

46. Syu, Y.Y.; Hung, J.H.; Chen, J.C.; Chuang, H.W. Impacts of size and shape of silver nanoparticles on Arabidopsis plant growth and gene expression. Plant Physiol. Biochem. 2014, 83, 57-64. [CrossRef] [PubMed]

47. Kaveh, R.; Li, Y.S.; Ranjbar, S.; Tehrani, R.; Brueck, C.L.; van Aken, B. Changes in Arabidopsis thaliana gene expression in response to silver nanoparticles and silver ions. Environ. Sci. Technol. 2013, 47, 10637-10644. [PubMed]

48. Simon, D.F.; Domingos, R.F.; Hauser, C.; Hutchins, C.M.; Zerges, W.; Wilkinson, K.J. Transcriptome sequencing (RNA-seq) analysis of the effects of metal nanoparticle exposure on the transcriptome of Chlamydomonas reinhardtii. Appl. Environ. Microbiol. 2013, 79, 4774-4785. [CrossRef] [PubMed]

49. Mustafa, G.; Sakata, K.; Komatsu, S. Proteomic analysis of flooded soybean root exposed to aluminum oxide nanoparticles. J. Proteom. 2015, 128, 280-297. [CrossRef] [PubMed] 
50. Schnackenberg, L.K.; Sun, J.; Beger, R.D. Metabolomics techniques in nanotoxicology studies. Methods Mol. Biol. 2012, 926, 141-156. [PubMed]

51. Burnum, K.E.; Frappier, S.L.; Caprioli, R.M. Matrix-assisted laser desorption/ionization imaging mass spectrometry for the investigation of proteins and peptides. Annu. Rev. Anal. Chem. 2008, 1, 689-705. [CrossRef] [PubMed]

(c) (C) 2015 by the authors; licensee MDPI, Basel, Switzerland. This article is an open access article distributed under the terms and conditions of the Creative Commons by Attribution (CC-BY) license (http://creativecommons.org/licenses/by/4.0/). 